\title{
ANALISIS DAMPAK PEMBANGUNAN SAMARINDA BARU (BSB) TERHADAP PROVINSI KALIMANTAN TIMUR
}

\author{
Adisthy Shabrina Nurqamarani \\ Faizal Reza \\ University of 17 Agustus 1945 Samarinda \\ J1. Ir. H. Juanda No. 80, Samarinda 75124, Indonesia \\ adisthy.shabrina@gmail.com
}

\begin{abstract}
This is a descriptive research regarding economic impact analysis of APT Pranoto Airport or called "Bandara Samarinda Baru" in East Kalimantan region. The aim of the project was to provide the evidence on the economic benefits resulted from Samarinda Baru airport by applying economic impact analysis. This article primarily focused on expenditure impacts as well as brief information of non-pecuniary impacts of Samarinda Baru airport project during operational phase.

At the research stage, the project focused on examining the previous literatures of economic impact studies at the same time as investigating reports on the Samarinda Baru airport. The project involved a strong element of analysis on academic literatures, reports from Dinas Perhubungan Kalimantan Timur and Unit Pengelola Bandar Udara (UPBU) Kalimantan Timur. The methodology applied input output approach based on multipliers and relies on secondary data collection as primary method.

The findings showed that there are numerous economic and non economic benefits resulted from the development of Bandara Samarinda Baru, included increase employment of local workers, increase expenditure within the region which impacted to better money circulation within the region, and also increase learning opportunities and create positive image towards cities around the airport location which in turn to economic welfare throughout East Kalimantan province. This finding can be used to emphasize Samarinda Baru airport contribution to East Kalimantan region and support its development in gaining funding and acceptance from local community.
\end{abstract}

Keywords: Economic Impact Analysis, Multiplier, Airport

\section{PENDAHULUAN}

Di era pemerintahan Presiden Joko

Widodo, pembangunan ekonomi di Indonesia diarahkan untuk peningkatan pertumbuhan ekonomi, untuk penciptaan tenaga kerja dan pengurangan kemiskinan. Guna mempercepat akselerasi dan memperkuat pembangunan. Pemerintah yang berperan sebagai perencana dan pelaksana pembangunan ekonomi sejak beberapa tahun yang lalu mencanangkan program jangka panjang yang disebut dengan program Masterplan Percepatan Perluasan dan Pembangunan Ekonomi Indonesia (MP3EI) (Restiana, 2012).

Sehubungan dengan agenda MP3EI dalam memperkuat konektivitas nasional yang terintregasi secara lokal dan terhubung secara global, Kalimantan 
Timur yang merupakan salah satu daerah Koridor Ekonomi Kalimantan turut serta mewujudkan cita-cita tersebut dalam bentuk peningkatan sistem transportasi yakni pembangunan bandara-bandara baru yang representatif. Pembangunan Bandara Samarinda Baru merupakan bentuk perwujudan dari Master Plan (MP3EI) yang juga meliputi pembangunan fasilitas lain seperti jalan free way dan rel kereta api baru yang rencananya terkoneksi ke bandara. Oleh karena itu, kehadiran bandara baru di Samarinda dirasa sangat medesak untuk menunjang kegiatan ekonomi masyarakat Kaltim pada khususnya dan program pembangunan pemerintah pada umumnya. Di samping itu kehadiran bandara juga dirasa penting penting bagi kelancaran aktivitas penduduk Indonesia yang merupakan negara kepulauan (Melati, 2013).

Kehadiran bandara memegang peranan penting untuk perekonomian daerah baik sebagai penunjang kebutuhan masyarakat ataupun untuk kebutuhan industri. Oleh karena itu kebutuhan untuk membangun Bandara Samarinda baru yang dapat menampung penerbangan ke kota-kota besar di Indonesia dirasa sangat mendesak, terutama mengingat Samarinda sebagai ibu kota provinsi. Meskipun Samarinda berfungsi sebagai ibukota Provinsi Kalimantan Timur dan kota terpadat, namun Balikpapan jauh lebih awal membangun sebuah bandara internasional, dan telah memperbaharui bandara yang dapat menampung 99,023 pax per tahun untuk rute internasional dan 7.628.594 pax per tahun untuk rute domestik.

\section{Kehadiran Bandara Samarinda} Baru, tentu juga diharap dapat menggeliatkan bisnis di kota Samarinda, dan menjadi lalu lintas perdagangan antar kota dan antar provinsi di Indonesia. Secara historis bandara Samarinda Baru dirancang sebagai pengganti bandara Samarinda terdahulu yaitu Bandara Temindung yang awalnya dibangun sebagai bandara perintis pada tahun 1973. Bandara Temindung sendiri terletak di Kecamatan Sungai Pinang Kota Samarinda yang dilengkapi dengan satu landasan pacu tunggal dan berada sangat dekat dengan kawasan pemukiman penduduk. Oleh karena Bandara Temindung hanya memiliki ruang terbatas untuk ekspansi pembangunan fasilitas bandara sehingga bandara ini dinilai tidak dapat lagi mengatasi lonjakan lalu lintas udara yang tiap tahun terus meningkat.

Pada awal tahun 2000an, Temindung telah menjadi salah satu bandara tersibuk di Kaltim dengan predikat jauh melebihi kapasitas desain penumpang dan kargo tahunan. Seiring 
perkembangan zaman, karena keterbatasan dalam menampung kapasitas penumpang secara optimal paling tidak terjadi satu dari setiap 25 penerbangan yang mengalami penundaan. Sebagian besar karena kurangnya ruang untuk pesawat, gerbang, dan landasan pacu. Kegiatan pembangunan Bandara Samarinda Baru sudah mulai dikerjakan sejak 15 Desember 2014 oleh PT Waskita Karya, Hutama Karya, dan Wijaya Karya dan sudah mulai beroperasi pada Juli 2018. Bandara Samarinda Baru dibangun di ibu kota di Kalimantan Timur di latar belakangi dari keterbatasan sarana transportasi udara yang saat ini tersedia di Samarinda.

Bandara Termindung hanya melayani penerbangan ke Balikpapan, Berau, Bulungan, Tarakan, Datah Dawai, dan Long Apung. Sedangkan, untuk menambah rute penerbangan ke kota-kota besar di Indonesia tidak memungkinankan karena lokasi Bandara Temindung berada di pemukiman padat penduduk. Oleh karena itu, Pemerintah Provinsi Kalimantan Timur kini terus mendorong dikerjakannya kegiatan pembangunan Bandara Samarinda Baru yang diproyeksikan akan menjadi Bandara Pendukung Bandara Sultan Aji Muhammad Sulaiman Sepinggan, Balikpapan. Ini sejalan dengan inisiatif pemerintah untuk mempromosikan sarana transportasi guna meningkatkan ekonomi (Neswari, 2012).

Bagaimanapun, kedekatan lokasi antara Bandara Samarinda Baru dan Bandara Internasional Sultan Aji Muhammad Sulaiman Sepinggan ini menjadi kendala bagi para penyandang dana atau investor. Bandara Sultan Aji Muhammad Sulaiman Sepinggan saat ini berfungsi sebagai bandara terbesar dan tersibuk di Kalimantan Timur. Pembangunan Bandara Samarinda Baru dikhawatirkan tidak memberi dampak siginifikan kepada investor dan juga dikhawatirkan akan mengurangi profitabilitas Bandara Sultan Aji Muhammad Sulaiman Sepinggan karena jumlah penumpang yang tentunya akan terbagi ke Bandara Samarinda Baru. Seperti dikutip dari Surat Kabar Online Kliksamarinda.com (2016). bahwa bahkan Angkasa Pura cemas akan terjadi persaingan antar bandara, jika BSB dikelola pihak lain dan untuk untuk mengelola BSB itu harus ada pembicaraan dan mempertimbangkaan aspek business to business.

Oleh karena itu, jika Bandara Samarinda Baru memiliki bukti yang cukup mengenai manfaat ekonominya, ini akan memungkinkan Proyek Bandara Samarinda Baru mendapatkan dukungan 
penuh dari pemerintah, penyandang dana, dan masyarakat

\section{TINJAUAN PUSTAKA}

Branch (1996) mengatakan bahwa perkembangan suatu kota dipengaruhi oleh dua faktor yaitu faktor eksternal dan faktor internal. Faktor eksternal merupakan suatu kekuatan yang terbentuk akibat kedudukan kota dalam konstelasi regional atau wilayah yang lebih luas, sehingga memiliki kemampuan untuk menarik perkembangan dari daerah sekitarnya. Faktor internal adalah kekuatan suatu kota untuk berkembang dan ditentukan oleh keuntungan letak geografis atau fungsi kota.

Kemudian Reksohadiprojo (2001) menyatakan bahwa perkembangan suatu kota juga dipengaruhi oleh perkembangan dan kebijakan ekonomi. Ia juga menyebutkan bahwa hal ini disebabkan karena perkembangan kota pada dasarnya adalah wujud fisik perkembangan ekonomi. Beberapa aspek yang dapat menentukan pertumbuhan dan perkembangan suatu kota, yaitu: perkembangan penduduk perkotaan menunjukan pertumbuhan dan intensitas kegiatan kota, kelengkapan fasilitas yang disediakan oleh kota dapat menunjukan adanya tingkat pelayanan bagi masyarakatnya, serta tingkat investasi yang hasilnya dapat menunjukan tingkat pertumbuhan kota hanya dapat tercapai dengan tingkat ekonomi yang tinggi.

Dalam konteks penelitian ini, Bandara Samarinda Baru merupakan wujud fisik perkembangan Kota Samarinda sebagai ibukota propinsi Kalimantan Timur yang memiliki intensitas kegitan industri dan kegiatan masyarakat yang tinggi sehingga keberadaan fasilitas bandara terdahulu, yaitu Bandar Udara Temindung tidak lagi ideal untuk berada di pusat kota.

Selain itu, merujuk pada peraturan pemerintah yang mengatur tingkat ketinggian bangunan di suatu kota jika terdapat bandara dalam kota tentunya membatasi pembangunan gedung-gedung tinggi di kota Samarinda jika bandara Temindung masih beroperasi di dalam kota. Hal ini juga melatarbelakangi berdirinya bandara Samarinda Baru yang terletak di pinggir kota (perbatasan antara Samarinda dan Kutai Kartanegara). Dengan ini, diharapkan kota Samarinda juga akan lebih berkembang. Dengan demikian, pembangunan Bandara Samarinda Baru di daerah Kota Samarinda yang berbatasan langsung dengan Kabupaten Kutai Kartanegara menjadi solusi pemindahan bandara lama. 
Dengan adanya pembangunan bandara Samarinda Baru, daerah Sungai Siring yang menjadi lokasi pembangunan Bandara Samarinda Baru pun akan ikut berkembang menjadi perkotaan yang lebih maju. Faktor ini didukung juga dengan perkembangan penduduk perkotaan yang senantiasa mengalami peningkatan. Peningkatan penduduk tersebut akan menimbulkan tuntutan akan kebutuhan kehidupan dalam aspek ekonomi, sosial, budaya, politik dan teknologi juga terus mengalami peningkatan, yang semuanya itu mengakibatkan meningkatnya kebutuhan akan ruang perkotaan yang lebih besar.

\section{DAMPAK PEMBANGUNAN}

BANDARA TERHADAP

\section{PEREKONOMIAN: APAKAH}

BENAR BERMANFAAT?

Sejumlah penelitian empiris sebelumnya telah dilakukan untuk meneliti hubungan antara lapangan kerja dan ketersediaan layanan transportasi udara internasional. Banyak dari ini melibatkan wawancara dengan bisnis lokal. Temuan umumnya menunjukkan bahwa jenis layanan ini dapat berpengaruh dalam mempengaruhi keputusan lokasi pengusaha. Sebuah studi awal di Atlanta, misalnya, yang melibatkan survei 264 perusahaan asing menemukan bahwa ketersediaan layanan internasional langsung merupakan faktor paling penting ketiga dalam keputusan lokasi perusahaan-perusahaan ini (Atlanta Chamber of Commerce, 1988a). Temuan ini konsisten di seluruh negara. Sebagai contoh, penelitian pada 57 perusahaan di Eropa menemukan bahwa jaringan transportasi udara adalah faktor paling penting ketiga dalam proses keputusan penentuan lokasi, khususnya pada perusahaan-perusahaan sektor jasa (Button \& Taylor, 2000).

Sebuah studi oleh UK's Civil Aviation Authority (1994) melihat pentingnya layanan internasional baru yang melibatkan bandara di luar London. Dalam hal layanan Atlantik Utara, itu dianggap implikasi ekonomi dari layanan baru antara Birmingham dan New York dan antara Manchester dan Atlanta. Studi ini pada dasarnya menggunakan pengganda dan menemukan bahwa, setelah mengijinkan efek pengalihan lalu lintas serta pembuatan lalu lintas, rute New York akan menghasilkan beberapa juta $£$ dalam manfaat penumpang dan layanan Atlanta sebesar $£ 1,2$ juta per tahun.

Permana (2009) menganalisis mengenai peranan dan dampak investasi infrastruktur terhadap perekonomian Indonesia, dengan menggunakan metode Analisis Input-Output. Hasil dari penelitian ini menemukan bahwa 
infrastruktur memiliki keterkaitan kebelakang (backward lingkage) yang lebih tinggi daripada keterkaitan ke depannya (forward lingkage) yang berarti bahwa infrastruktur lebih berperan dalam meningkatkan output sector lain untuk digunakan sebagai input dibandingkan dengan kemampuannya dalam meningkatkan output sector lain yang menggunakan input dari infrastruktur. Pertumbuhan investasi pada sector Listrik, gas, dan air bersih memberikn dampak terbesar terhadap perubahan output total, sedangkan sektor pengangkutan dan komunikasi memberikan dampak terbesar terhdap perubahan pendapatan dan tenaga kerja total.

Neswari (2012) dalam penelitian "Dampak Pembangunan Bandara Internasional Lombok Terhadap Perekonomian Provinsi Nusa Tenggara Barat" menyimpulkan bahwa sektor bangunan (bandara) memiliki keterkaitan ke belakang yang lebih besar dibanding keterkaitan ke depan, artinya pembangunan bandara mampu meningkatkan pertumbuhan sektor hulunya. Lebih jauh disimpulkan pula bahwa adanya pembangunan bandara turut meningkatkan output dan pendapatan rumah tangga provinsi NTB.

Restiana (2012) dalam penelitian "Peranan Investasi Pembangunan
Infrastruktur Transportasi Dalam Perekonomian Daerah, Studi Kasus: Bandara Udara Sepinggan- Kalimantan Timur" menyimpulkan bahwa pembangunan Bandar Udara Sepinggan memiliki kemampuan untuk meningkatkan permintaan output dari sektor lain yang akan dijadikan input dibandingkan kemampuannya dalam menghasilkan output yang akan digunakan sebagai input sektor lain berarti bahwa sektor bangunan lebih mendorong pertumbuhan sektor hulunya. Berdasarkan simulasi investasi yang dilakukan, pembangunan Bandara Internasional Sepinggan dapat meningkatkan output dan pendapatan rumah tangga masyarakat.

\section{ANALISIS DAMPAK EKONOMI}

Staley (2010) mengemukakan bahwa analisis dampak ekonomi yang menggunakan metode input-output dengan menerapkan pengganda mempunyai beberapa kekurangan. Pertama, metode input-output tidak dapat memberikan perkiraan yang tepat tentang dampak dunia nyata karena ia tidak dapat mengendalikan banyak faktor yang mungkin mempengaruhi ukuran dan saling ketergantungan uang yang mengalir melalui ekonomi regional dengan sektor ekonomi yang beragam. 
Staley (2010) menunjukkan contoh kelemahan pengganda yang memperkirakan konstruksi perumahan pada resesi ekonomi akan tidak akurat jika berdasarkan pengganda yang digunakan selama puncak booming perumahan. Kritik lain adalah bahwa pengganda berdasarkan dampak ekonomi tidak berakar pada analisis efisiensi pengeluaran karena mereka tidak memperhitungkan pendapatan yang dialihkan dari bagian lain dari ekonomi, atau biaya peluang karena pengalihan tersebut (Staley, 2010).

Lebih lanjut, Fjeldsted (1990) menyimpulkan bahwa pengganda sering digunakan secara sengaja untuk memuaskan kepentingan sektor tertentu. Penggunaan pengganda untuk tujuan prediksi dampak sering menggabungkan asumsi bahwa koefisien teknis dapat berubah untuk beberapa alasan yang berbeda. Akibatnya, ini dapat membatalkan penggunaan pengganda turunan input-output untuk tujuan produksi. Mills (1993) menunjukkan bahwa studi analisis dampak ekonomi sering disalahgunakan oleh pemerintah negara bagian dan lokal dan konsultan mereka. Karena kebutuhan pemerintah negara bagian dan lokal untuk mengumpulkan uang untuk membiayai biaya modal proyek yang diusulkan, seringkali hasil proyek seperti itu dapat dimanipulasi untuk memenuhi harapan klien atau sponsor.

\section{KERANGKA PIKIR}

Sehubungan dengan peran Kalimantan Timur dalam agenda MP3EI dalam memperkuat konektivitas nasional yang terintregasi secara lokal dan terhubung secara global, serta untuk menunjang perekonomian provinsi Kalimantan Timur, kehadiran bandara baru di Samarinda dirasa sangat medesak. Gambar 1 mengilustrasikan konsep keterkaitan ekonomi dari proyek Bandara Samarinda Baru. Ketika perusahaan berinvestasi pada pembangunan infrastruktur, khususnya Bandara, ini akan dan juga pada perekonomian suatu wilayah. 


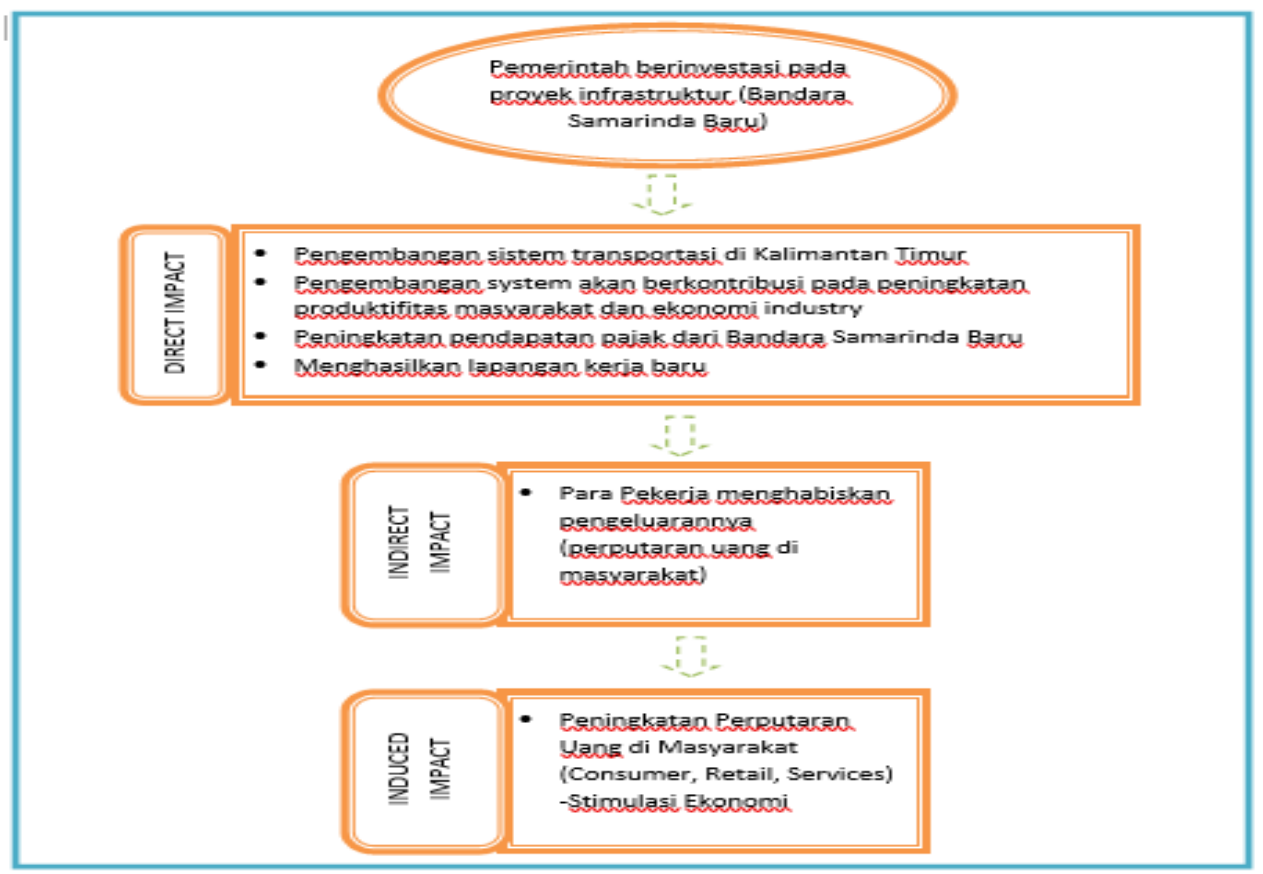

\section{Gambar 1. Kerangka Pikir}

\section{METODE}

\section{Tempat Dan Waktu Penelitian}

Lingkup lokasi penelitian adalah pada wilayah Kalimantan Timur. Penelitian dilaksanakan dalam rentang waktu selama kurang lebih 7 bulan sampai dengan pembuatan laporan kemajuan. Aktivitas pengambilan data dilakukan di Dinas Perhubungan Kalimantan Timur dan Unit Pengelola Bandar Udara Samarinda Baru.

\section{Metode Pengumpulan Data}

Pengumpulan data dilakukan dengan secondary research melalui literatur dan data expenditure dan employment dari proyek Bandara
Samarinda Baru. Peneliti akan melakukan penelitian sekunder dengan mengumpulkan data pengeluaran proyek dan belanja operasional pada setiap tahap pembangunan bandara, serta dampak penggajian dan ketenagakerjaan. Ini akan diperoleh dari penelitian sebelumnya (review literature), catatan perusahaan serta publikasi dan buku online, jurnal, majalah, berita, dan lain-lain.

\section{Model}

Metodologi yang digunakan dalam makalah ini adalah model Multiplier Analysis, yang mempelajari pengaruh proyek tertentu terhadap perekonomian secara keseluruhan. Analisis ini akan berfokus pada perkiraan dampak langsung, 
tidak langsung dari Bandara Samarinda Baru di wilayah Kalimantan Timur khususnya Samarinda melalui penggunaan multipliers (angka pengganda).

Dengan demikian, perkiraan pengeluaran bandara, penyewa bandara dan pengunjung yang melewati bandara dan menyebar melalui kawasan ekonomi negara sehingga menciptakan lapangan kerja tambahan dan nilai akan dipertimbangkan. Selanjutnya, analisis sensitivitas dilakukan dengan menghitung efek pengganda yang berbeda untuk memperkirakan dampak dan menguji sensitivitas hasilnya.

\section{ANALISIS DAN PEMBAHASAN}

Analisis mencakup tiga sub-langkah; mengukur nilai tambah bruto (GVA) dan perkiraan pekerjaan yang dihasilkan dari proyek, membangun model input-output, dan menerapkan pengganda ke data pengeluaran untuk mendapatkan dampak. Analisis ini secara khusus membahas dampak ekonomi pada fase operasional.

Mengukur Nilai Tambah Bruto (GVA)

Dan Perkiraan Pekerjaan Yang

Dihasilkan dari Proyek

Total GVA adalah jumlah GVA langsung, tidak langsung, dan induksi.
GVA dalam proyek penelitian ini akan dibagi menjadi GVA langsung dan GVA operasional. GVA langsung akan digunakan pada fase konstruksi sementara GVA tidak langsung akan digunakan dalam fase operasional. Dalam artikel ini, dikhususkan pada fase operasional.

Fase Operasional. Untuk mengukur dampak ekonomi dari fase operasional, peneliti menggunakan estimasi dari pengeluaran operasional bandara. Pada penelitian ini, peneliti mengidentifikasi sumber dari pengeluaran tersebut apakah berasal dari area Kalimantan Timur, atau scope Indonesia ataupun impor dari luar negeri. Jika diimpor dari luar negeri, GVA akan lebih rendah. Meskipun demikian, karena bandara belum beroperasi secara optimal dan per 15 November masih terbatas melayani penerbangan lokal di satu pulau maka dampak ekonomi tidak dapat secara optimal dikalkulasi.

Tabel 1 menunjukan, total pengeluaran modal (Operational Expenditure) dikurangi payroll dan leakage $30 \quad \%$ sebesar IDR 62,924,555,500. Selanjutnya angka tersebut dikalikan dengan multiplier coefficient untuk menghitung dampak sekunder (indirect and induced impact), didapatkan nilai $\operatorname{Rp} 66,724,939,500$. 
Tabel 1. Dampak Pengeluaran Pada Fase Operasional

Deskripsi

Est. Operational Expenditure

Minus payroll

Minus leakage (30\%)

Direct Expenditure

Direct expenditure impact

Multiplier coefficient

Estimated indirect and induced impact

Total (Combined direct, indirect, and in IDR duced impact)

\section{Sensitivity Analysis Pada Fase}

\section{Operasional}

Untuk meningkatkan akurasi dari hasil penelitian ini, peneliti melakukan sensitivity analysis dengan membandingkan hasil dari beberapa alternative multiplier dan menghitung dampaknya terhadap provinsi Kalimantan Timur.

Angka multiplier sebesar 1.6876 dipilih sebagai alternatif multiplier. Peneliti juga menghitung beberapa

Tabel 2: Sensitivity Analysis - Leakage Based

IDR

\section{Total}

IDR

IDR

$9,948,486,000.00$

IDR

$31,231,303,500.00$

IDR

$62,924,555,500.00$

$62,924,555,500.00$

IDR

1.00499

$3,800,384,000.00$

$66,724,939,500.00$

skenario dari tingkat kebocoran (leakage) yang berbeda. Analisis ini menjelaskan dampak pengganda terhadap output. Untuk provinsi Kalimantan Timur, kenaikan angka pengganda sebesar 0.7 mengakibatkan kenaikan dampak langsung dan tidak langsung sebanyak $\mathrm{Rp}$ 44,990,211,638.39. Ini menunjukan bahwa dampak pengeluaran sangat sensitif terhadap perubahan angka pengganda baik pada fase kontruksi, maupun fase operasional.

\section{Leakage \\ Direct expenditure}

\begin{tabular}{llll}
$20 \%$ & $75,324,687,200.00$ & $75,700,557,389.13$ & $151,025,244,589.13$ \\
\hline $30 \%$ & $65,909,101,300.00$ & $66,237,987,715.49$ & $132,147,089,015.49$
\end{tabular}




\begin{tabular}{cccc}
$40 \%$ & $56,493,515,400.00$ & $56,775,418,041.85$ & $113,268,933,441.85$ \\
\hline $50 \%$ & $47,077,929,500.00$ & $47,312,848,368.21$ & $94,390,777,868.21$ \\
\hline $60 \%$ & $37,662,343,600.00$ & $37,850,278,694.56$ & $75,512,622,294.56$ \\
\hline $70 \%$ & $28,246,757,700.00$ & $28,387,709,020.92$ & $56,634,466,720.92$ \\
\hline $80 \%$ & $18,831,171,800.00$ & $18,925,139,347.28$ & $37,756,311,147.28$
\end{tabular}

Tabel 3 : Senstivity Analysis - Multiplier Based

\section{Multiplier Coefficient \\ Estimated Indirect and Induced Impact}

\section{Total Expenditure Impact}

\begin{tabular}{lrrrrr}
\hline $\begin{array}{l}1.6876 \\
\text { Balikpapan, 2015) }\end{array}$ & IDR & $11,228,199,353.88$ & IDR & $177,137,300,653.88$ \\
\hline $\begin{array}{l}1.00499 \\
\begin{array}{l}\text { coefficient- } \\
2010)\end{array}\end{array}$ & BPS, & IDR & $66,237,987,715.49$ & IDR & $132,147,089,015.49$
\end{tabular}

\section{Key Impact Statement: Employment}

Berdasarkan data yang didapatkan dari UPBU Samarinda Baru, pada fase operasional jumlah tenaga kerja berjumlah \pm 207 personil (per September 2018) dengan perbandingan 1:69 untuk tenaga luar Kaltimtara vs tenaga local Kaltimtara.

\section{Learning opportunities}

Pembangunan Bandara akan berpengaruh positif terhadap pendidikan masyarakat lokal. Dengan adanya bandara, proses pertukaran barang dan perjalanan menjadi lebih mudah sehingga akan lebih mudah juga mendatangkan para expert yang berasal dari luar Kalimantan agar melaksanakan seminar ataupun workshop di beberapa kota di Kalimantan Timur, tidak hanya di Balikpapan.

Hal ini karena sebelumnya banyak yang keberatan akan beratnya medan dari Balikpapan ke Samarinda yang memakan waktu kurang lebih 3-4 jam dan melalui jalan yang berliku-liku. Oleh karena itu, dengan adanya Bandara di Kota Samarinda akan menarik para expert untuk mengadakan acara bertema pendidikan di kota-kota yang sebelumnya berat untuk ditempuh dengan jarak darat dan juga membuka peluang kota di sekitar Samarinda, Bontang, dan Sangatta untuk lebih berkembang dan merata ekonominya. 
Selanjutnya, sebagai kebutuhan pelatihan untuk pengembangan bandara dan pariwisata diidentifikasi, ini menciptakan dorongan kuat untuk memulai peluang baru untuk mengembangkan keahlian dalam bidang terkait infrastruktur, penerbangan dan pariwisata di Kalimantan Timur. Universitas di Kalimantan Timur dapat memanfaatkan peluang untuk membuat modul baru atau kursus tentang teknologi yang terkait dengan penerbangan dan pariwisata. Namun, masih sedikit literatur yang menunjukan bukti terkait kesempatan belajar yang didapat dari proyek Bandara Bandara Samarinda Baru karena proyek demonstrasi baru saja dimulai. Akibatnya, dampak dari penelitian, pengembangan dan penyebaran yang ditargetkan dari investasi bandara Samarinda Baru ini masih kurang dipahami pada saat ini.

\section{Perluasan dan Pemeliharaan}

Infrastruktur

Proyek pembangunan bandara juga membawa manfaat bagi masyarakat setempat termasuk perluasan dan pemeliharaan infrastruktur. Namun, sejauh mana manfaat akan dipertanyakan apakah infrastruktur baru akan dibangun atau apakah itu dapat mengakibatkan peningkatan lalu lintas lokal atau kerusakan potensial pada jalan-jalan yang ada karena kendaraan berat

\section{KESIMPULAN DAN SARAN}

Tinjauan literatur mempresentasikan bukti manfaat proyek pembangunan bandara terhadap suatu wilayah baik secara ekonomi dan non-moneter. Manfaat ekonomi termasuk peningkatan pengeluaran dan penciptaan lapangan kerja yang mengarah pada peningkatan PDB daerah setempat, sementara manfaat non-keuangan mencakup citra merek yang positif bagi kota dimana bandara itu dibangun (Samarinda) serta memudahkan akses penduduk di kota-kota sekitar Samarinda seperti Sangatta, Bontang untuk melakukan penerbangan lokal (sementara) dan domestik serta internasional (jangka panjang).

Selanjutnya, temuan penelitian menunjukkan dampak ekonomi yang proyek bandara bawa ke daerah yaitu peningkatan pengeluaran. Untuk dampak ekonomi terkait peningkatan lapangan kerja belum didapatkan data real dari narasumber untuk fase kontruksi. Namun, ada juga beberapa kekhawatiran yang harus diperhitungkan untuk mendapatkan manfaat maksimal dari proyek ke wilayah termasuk peluang kebocoran aliran uang yang keluar dari area penelitian (Kalimantan Timur), serta kurangnya permintaan di Bandara Samarinda Baru karena letaknya yang tidak terlalu jauh dari Bandara Aji Sultan Ali Muhammad 
Sulaiman Sepinggan di kota Balikapapan.

Dalam bab terakhir dari proyek ini, diharapkan akan berguna bagi pembaca dan peneliti untuk mendapatkan lebih banyak pengetahuan yang berkaitan dengan dampak pembangunan bandara untuk masyarakat.

Berdasarkan hasil penelitian dan pembahasan dapat dikemukakan saran yaitu sebagai berikut:

1. Untuk memperoleh dampak ekonomi yang signifikan terhadap area Kalimantan Timur, sebaiknya pemerintah provinsi mempunyai akses data mengenai tenaga kerja yang dipakai baik dalam fase konstruksi ataupun operasional dan mengatur kebijakan mengenai proporsi tenaga kerja yang dipakai. Hal ini dimaksudkan untuk mencegah kebocoran aliran uang agar tetap berada di area Kalimantan Timur.

2. Pemerintah Provinsi Kalimantan Timur beserta Dinas dan Pihak terkait mempunyai peranan penting dalam memajukan perekonomian provinsi Kalimantan Timur. Oleh karena itu, pihak Dinas dan Mitra terkait seharusnya lebih bersikap transparan dan responsif atas permohonan data penelitian yang ditujukan untuk kepentingan propinsi Kalimantan Timur.

3. Keberadaan bandara mampu mengembangkan sektor pariwisata dan mendatangkan lebih banyak penumpang karena semakin mudahnya akses menuju Provinsi Kalimantan Timur, khususnya daerah kota Samarinda, Bontang, Sangatta yang letaknya cukup jauh jika ditempuh dari Bandara Sepinggan Balikpapan. Oleh karena itu, pemerintah harus merampungkan proyek bandara dengan cepat agar beroperasi secara maksimal untuk mengembangkan perekonomian Provinsi Kalimantan Timur.

4. Pemerintah Provinsi Kalimantan Timur beserta Dinas dan Pihak terkait sebaiknya menyusun Tabel Input Output (I-O) Provinsi Kalimantan Timur secara berkala. Data Tabel I-O terakhir provinsi Kalimantan Timur adalah data tahun 2011 yang mana seharusnya sudah dilakukan pembaharuan tiap 5 tahun sekali. Dengan penyusunan Tabel I-O secara berkala, Pemerintah dan para peneliti akan mempunyai data yang lebih update untuk menganalisis kondisi perekonomian Kalimantan Timur 
dan menentukan sector yang paling berkontribusi pada perekonomian.

5. Penelitian ini masih terdapat banyak keterbatasan terutama data yang masih belum diperoleh sampai laporan kemajuan ini dibuat, untuk itu diharapkan perlu

\section{REFERENCES}

Atlanta Chamber of Commerce. 1988a. International Air Service as a Location Determinant for Foreign Business Atlanta, Atlanta.

Atlanta Chamber of Commerce. 1988b. The Economic Value of International

Air Service to Atlanta and Georgia. Atlanta.

Bappeda Prov. Kalimantan Timur. 2018. Profil Daerah Kalimantan Timur. Samarinda: $\quad$ Bappeda Prov. Kalimantan Timur.

Bappeda Kota Balikpapan. 2015. Tabel Input Output Kota Balikpapan. Balikpapan: Bappeda Kota Balikpapan.

Badan Pusat Statistik (BPS) and Bappeda Prov. Kalimantan Timur. 2018. Tabel Input Output Kalimantan Timur. Samarinda: Badan Pusat Statistik.

Branch, C M. 1996. Perencanaan Kota Komprehensif. Yogyakarta: Gadjah Mada University Press.

Button, Kenneth J. \& Taylor, Samantha Y. 2000. International Air Transportation And Economic Development. 40th Congress of the European Regional Science Association: "European Monetary Union and Regional Policy". Barcelona, Spain. dilakukan penelitian lanjutan dengan data yang lebih terbaru dan klasifikasi sektor yang lebih banyak.

Fjelsted, B.L., 1990. Regional Input Output Multipliers: Calculation, Meaning, Use and Misuse. Utah Economic and Business Review, Vol.50 (10).

Janeczko, B., Mules, T., \& Ritchie, B. 2002. Estimating the Economic Impact of Festivals and Events: a Research Guide. Diambil dari: http://www.crctourism.com.au/wms/u pload/resources/bookshop/Mules_Eco ImpactsFestivals_v6.pdf. Diakses pada 1 Agustus 2018.

Melati, Aisya. Nadhira. 2013. Analisis Ekonomi Lingkungan Bandar Udara Soekarno Hatta. Diambil dari: https://anzdoc.com/analisis-ekonomi-1 ingkungan-bandar-udara-soekarno-hat ta-aisy.html. Diakses pada 14 Januari 2018 .

Mills, E.S., 1993. The Misuse of Regional Economic Models. CATO Journal, 13 (1), pp.29-39.

Morgan, Jonathan Q. 2010. Analysing the Benefits and Costs of Economic Development Projects. Retrieved from sogpubs.unc.edu/electronicversions/p dfs/cedb7.pdf. Accessed on 3 March 2018.

Neswari, Ken. Ardhana. 2012. Dampak Pembangunan Bandara Internasional Lombok Terhadap Perekonomian Provinsi Nusa Tenggara Barat. 
Diambil dari: https://repository.ipb.ac.id/jspui/bitstr eam/123456789/.../10/H12kan.pdf.

Diakses pada 12 Januari 2018.

Permana, C.H. 2009. Analisis Peranan Dan Dampak Investasi Infrastruktur Terhadap Perekonomian Indonesia: Analisis Input-Output. Diambil dari: https://repository.ipb.ac.id/jspui/bitstr eam/123456789/11590/2/H09cdp.pdf. Diakses pada 1 Juli 2018.

Redding, L. and Schatzel, K. 2006. Market Survey Director Detroit Metropolitan Wayne County Airport 2006 Economic Impact Study. Diambil dari: http://www.umdilabs.com/sites/defaul t/files/DTW_Economic_Impact_Repo rt.pdf. Diakses pada 2 Juni 2018.

Reksohadiprojo, S. 2001. Ekonomika Publik. Yogyakarta: BPFE.
Restiana, Dina dan Priyarsono D. S. 2012. Peranan Investasi Pembangunan Infrastruktur Transportasi Dalam Perekonomian Daerah (Studi Kasus: Pembangunan Bandar Udara Sepinggan-Kalimantan Timur). Diambil dari: https://repository.ipb.ac.id/handle/123 456789/56152. Diakses pada 2 January 2018 .

Staley, 2010. The use and abuse of multipliers [online]. Diambil dari: : http://www.planetizen.com/node/4341 7. Diakses pada 5 Juni 2018

UK Civil Aviation Authority. 1994. The Economic Impact of New Air services: A Study of Long Haul Services at UK Regional Airports. London: Civil Aviation Authority.

\section{Penelitian ini didanai oleh Direktorat Jenderal Penguatan Riset dan Pengembangan Kementerian Riset, Teknologi dan Pendidikan Tinggi dengan nomor kontrak} 509/KONTRAK-PENELITIAN/K11/KM/2018 Tgl 22 Februari 2018 